\title{
Article
}

\section{COVID-19 vaccine calculations}

Davies, Janice Anne

Available at http://clok.uclan.ac.uk/37210/

Davies, Janice Anne (2021) COVID-19 vaccine calculations. Journal of Prescribing Practice, 3 (3). p. 106. ISSN 2631-8385

It is advisable to refer to the publisher's version if you intend to cite from the work.

10.12968/jprp.2021.3.3.106

For more information about UCLan's research in this area go to

http://www.uclan.ac.uk/researchgroups/ and search for <name of research Group>.

For information about Research generally at UCLan please go to http://www.uclan.ac.uk/research/

All outputs in CLoK are protected by Intellectual Property Rights law, including Copyright law. Copyright, IPR and Moral Rights for the works on this site are retained by the individual authors and/or other copyright owners. Terms and conditions for use of this material are defined in the policies page.

\section{CLoK}

Central Lancashire online Knowledge www.clok.uclan.ac.uk

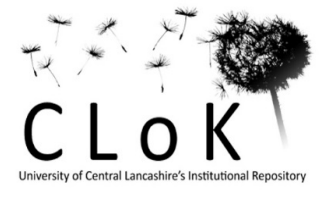




\section{COVID-19 vaccine calculations}

W orking in the COVID-19 vaccine store room at a Primary Care Network (PCN) vaccination site means that numeracy skills are in constant use. A good level of numeracy is required in order to ensure the correct number of vaccines are prepared for the patients booked in, and to prevent wastage of prepared vaccine.

Practice these questions, typical of the calculations carried out on clinic days.

\section{QUESTION 1}

One box of Pfizer vaccine contains 195 vials. Each vial produces six vaccine doses after reconstitution. How many vaccine doses can be administered from one box of Pfizer vaccines?

\section{QUESTION 2}

The Pfizer vaccine has a 5 day expiry date once it is removed from the deep freezer. Therefore, clinics at the PCN site are typically held for the 3 days following receipt of the vaccine. How many patients should be booked in each day?

\section{QUESTION 3}

How many vials need to be prepared each day?

\section{QUESTION 4}

It is one hour before the clinic closes and there are still 30 patients due in. How many vials need to be prepared for these patients?
The Astra Zeneca vaccine is less fragile and more transportable to off-site locations, such as care homes or patients' own homes. There are two presentations of the vials:

8-dose vials

10-dose vials.

If an extra dose can be extracted from the vial, it is permissible to administer this to a patient. It is not possible to know in advance if an extra dose can be extracted.

\section{QUESTION 5}

If there are three vaccinators doing home visits in one morning and they take one 10-dose vial each, how many patients should be:

a) Given an appointment?

b) On the reserve list?

gov.uk. Information for Healthcare Professionals on Pfizer/ BioNTech COVID-19 vaccine. 2021a. https://www.gov.uk/ government/publications/regulatory-approval-of-pfizerbiontech-vaccine-for-covid-19/information-for-healthcareprofessionals-on-pfizerbiontech-covid-19-vaccine (accessed 28 January 2021)

gov.uk. Information for Healthcare Professionals on COVID-19 Vaccine AstraZeneca. 2021b. https://www. gov.uk/government/publications/regulatory-approval-ofcovid-19-vaccine-astrazeneca/information-for-healthcareprofessionals-on-covid-19-vaccine-astrazeneca (accessed 28 January 2021)

Janice Davies MRPharmS

Pharmacist Co-Course Leader - Non Medical Prescribing

University of Central Lancashire

JADavies5@uclan.ac.uk 